\title{
The assemblage of epigean ants (Formicidae) inhabiting altered patches found in a latitudinal transect of coastal matorral of semiarid Chile
}

\author{
Ensambles de hormigas epigeas asociadas a parches alterados encontrados en un \\ transecto latitudinal del matorral costero del semiárido de Chile
}

\author{
Jorge Cepeda-Pizarro $^{1 *}$, Jaime Pizarro-Araya ${ }^{1,2}$, Víctor Bravo-Naranjo ${ }^{1,2}$
}

\begin{abstract}
The aims of the study were to document taxonomically the composition of the assemblage; estimate its species richness, and describe the effect of latitudinal gradient and matorral condition on species relative abundance and species richness of assemblage. The ants were caught with interception traps (pitfall type). The study was conducted between 2008 and 2011. We recorded the presence of four endemic species and one introduced. Maximum R was estimated at six. Solenopsis gayi (Myrmicinae) and Tapinoma antarticum (Dolichoderinae) were the numerically dominant species. We observed an effect of both the latitudinal floor of matorral and the matorral condition on the relative abundance of the species, particularly in the case of endemic species. This effect did no follow neither the latitudinal gradient nor the matorral condition. The ants' responses were species specific, with influence of the study site over that provided by latitudinal gradient and matorral condition. The distribution of estimated $\mathrm{R}$ did not show a clear pattern in any of the two cases. We believe that our results show a complex situation derived from the interweaving of influences due both to the historical rainfall gradient and its concomitant effect on vegetation, the current state of matorral, and the severe drought recorded during the study. It is possible that under conditions of mean precipitation or above, the results are different.

Key words: SouthAmerican deserts, desertification, ecosystem rehabilitation, soil fauna, invasive species.
\end{abstract}

\section{RESUMEN}

Los propósitos del estudio fueron documentar taxonomicamente la composición del ensamble; estimar su riqueza de especies y describir el efecto del gradiente latitudinal y la condición del matorral sobre la abundancia relativa de las especies y la riqueza del ensamble. Las hormigas fueron capturadas con trampas de intercepción de caída (tipo pitfall). El estudió fue realizado entre 2008 y 2011. Registramos la presencia de cuatro especies endémicas y una introducida. El R máximo se estimó en seis. Solenopsis gayi (Myrmicinae) y Tapinoma antarticum (Dolichoderinae) fueron las especies numéricamente dominantes. Observamos un efecto del piso latitudinal del matorral y de la condición de éste sobre la abundancia relativa de las especies, particularmente en el caso de las especies endémicas. Este efecto no siguió ni el gradiente latitudinal ni la condición del matorral. Estas respuestas fueron especie-específicas, con influencia del sitio de estudio. La distribución de R-estimado no mostró un patrón evidente en ninguno de los dos casos. Consideramos que nuestros resultados evidencian una situación compleja derivada del entrelazamiento de influencias debidas a la gradiente pluviométrica histórica y a su efecto concomitante sobre la vegetación, al estado actual del matorral y a la sequía severa a la que éste estuvo sujeto durante el estudio. Es posible que bajo condiciones de precipitación promedio o superior, los resultados sean diferentes.

Palabras clave: Desierto sudamericano, desertificación, rehabilitación de ecosistemas, introdución de especies, fauna de suelo, especies invasoras.

\section{Introduction}

One of the most severe environmental problems affecting Chile is desertification. Presently, about 48 million hectares ( 63\% of mainland Chile) are being affected (Alfaro, 2006). Desertification processes in Chile are believed to intensify as a result of effects of climate change (CONAMA, 2006). Nearly $22 \%$ of Chilean affected land is located in the coastal fringe and in the hilly inland of semiarid territory (Pérez \& González,

\footnotetext{
Laboratorio de Entomología Ecológica, Departamento de Biología, Universidad de La Serena, Casilla 554, La Serena, Chile 2 Instituto de Investigación Multidisciplinar en Ciencia y Tecnología, Universidad de La Serena, La Serena, Chile

* Corresponding Author: jcepeda@userena.cl
}

Fecha de Recepción: 8 septiembre, 2017.

Fecha de Aceptación: 25 abril, 2018.

DOI: http://dx.doi.org/10.4067/S0718-34292018005000401. Publicado en línea: 09-agosto-2018. 
2001). Over the last decades, in this part of the country, state agencies have intensively conducted programs based on shrub and tree-life forms to mitigate desertification (Bars, 2002). As a result, the present-day landscape is a mixture of degraded, afforested, and partially altered matorral. One of the plant species most intensively used has been Acacia saligna (Labill.) H. Wendl. (Fabaceae, Mimosoideae), an introduced Australian species. Despite this fact, from an ecosystem viewpoint there is a lack of knowledge regarding its effects on soil biotic elements of matorral of coastal semi-arid Chile.

Due to their different ecological roles, arthropods are considered as one of the most important biotic components of arid ecosystems, and one of the first groups of animals to be affected by desertification (Whitford, 2001). They also meet a series of requirements that make them quite suitable for monitoring rehabilitation efforts. This is the case of Formicidae (Hoffmann, 2010). Nevertheless, knowledge on ecology of Chilean ant species is rather scanty (TorresContreras, 2001). We pursued the following goals in this study: (1) to taxonomically document the assemblage across a latitudinal stretch of coastal matorral and matorral condition; 2) to estimate species richness across the above mentioned factors, and 3) to describe the effect of latitudinal gradient and matorral condition on ant relative abundance (density/activity) and species richness.

\section{Materials and Methods}

The study encompassed a transect extending from Las Tacas $\left(30^{\circ} 06^{\prime} 33^{\prime \prime} \mathrm{S}, 71^{\circ} 21^{\prime} 29^{\prime \prime} \mathrm{W}\right)$ to the Quereo Power Substation (31 $56^{\circ} 08^{\prime \prime}$ S, $71^{\circ} 28^{\prime} 46^{\prime \prime} \mathrm{W}$ ) (Figure 1). The historical annual precipitation ranges from $104 \mathrm{~mm}$ (northern margin) to $210 \mathrm{~mm}$ (southern margin). Data recorded by the Meteorological Office of the Chilean Navy (unpublished), show that this gradient was not clearly expressed during the study years. Across transect, soils are sandy to loamy-sandy in texture, low to very low in organic matter, $\mathrm{N}$, and $\mathrm{P}$ contents, but high to very high in the K-content. They correspond to stabilized dunes characterized by lack of diagnostic horizons. The transect crossed three latitudinal sections of matorral. From north to south, they were the low open shrubland (northern sector, matorral estepario costero in Spanish), the brushwood shrubland (central sector, matorral estepario boscoso), and the sclerophyllous shrubland (southern sector, matorral estepario arborescente). Details of original vegetation of the transect are provided by Luebert \& Pliscoff (2006). Nowadays, as a result of dryland agriculture and cattle-raising, clear-cutting, and afforestation actions, several matorral-conditions (patch-types) can be recognized within the landscape of these sections.

\section{Study design, specimen collection, and data analysis}

For each latitudinal section of matorral (hereafter "PLV"), we selected three sites simultaneously featuring non-rehabilitated degraded land (DES-patches), degraded land afforested with A. saligna (ASA-patches), and land in semi natural (VSN-patches). The DESpatches lacked shrubby vegetation, though there was a poorly developed herbaceous layer formed by native and introduced species. The ASApatches corresponded to A. saligna plantations ten or more years old with coverage above $40 \%$. The VSN-patches corresponded to remnants of original matorral, altered by goat-grazing. Ants were captured using 30-pitfall interception traps installed in each of the patch types. The traps operated for three days in September/October from 2008 to 2011. To prevent oversampling, the grids were yearly moved within each site. The specimens were identified at species level following Snelling \& Hunt (1975). Species richness was estimated using the Chao \& Lee-1 (ACE), jackknife 1, and rarefaction (grouped, finite) estimators. The calculations were performed in the Species Diversity and Richness IV software (Seaby \& Henderson, 2007).

\section{Results}

\section{Taxonomic structure and numerical dominance of ant species}

We captured 42767 ants, grouped in five species, four of them endemic. The species numerically dominant were $S$. gayi and $T$. antarcticum (Table 1). Across latitudinal sections, the largest contribution came from the middle 


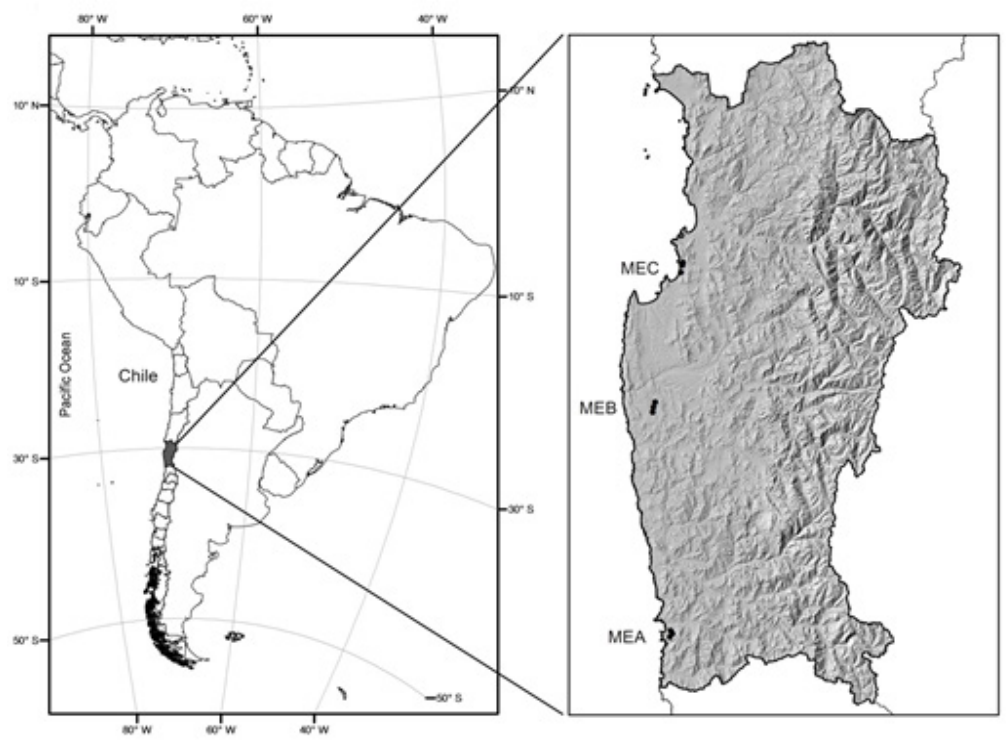

Figure 1. Geographic location of latitudinal sections of coastal shrubland studied in this work. Code for latitudinal section of shrubland (PLV): MEC: low open matorral; MEB: scrubby matorral; MEA: sclerophyllous matorral The small black dots show the study site locations. Distance between groups of sites: MEC-MEB: $80 \mathrm{~km}$; MEB-MAE: $120 \mathrm{~km}$. The landforms shown on the right side of the digital elevation model are the Andes Mountains.

Table 1. Taxonomic and ecological characteristics of assemblage of epigean ants recorded in a coastal stretch of

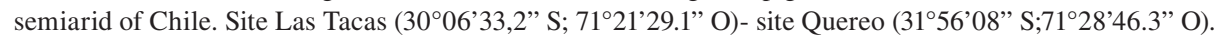

\begin{tabular}{lllllr}
\hline Species & Subfamily & Origin & Food habits & $\mathrm{n}$ & $\%$ \\
\hline Camponotus morosus & Formicinae & Endemic & Omnivore & 3970 & 9.28 \\
Linepithema humile & Dolichoderinae & Introduced & Oportunistic & 5825 & 13.62 \\
Pogonomyrmex bispinosus & Myrmicinae & Endemic & Granivore & 4223 & 9.87 \\
Solenopsis gayi & Myrmicinae & Endemic & Granivore & 17365 & 40.60 \\
Tapinoma antarcticum & Dolichoderinae & Endemic & Oportunistic & 11384 & 26.62 \\
\hline Total & & & & 42767 & 100 \\
\hline
\end{tabular}

*Numbers as catch by pitfall-traps.

sector (MEB, Figure 1), with a total captures of ca. 59\% (Table 2). Among patch-type, the highest percentage of captured specimens occurred in the Acacia saligna-patch (Table 3). Details of distribution of abundance across latitudinal section and matorral condition are provided by Figures 2 through 6 . Out of 10 paired comparisons of relative abundance (non-parametric Spearman's rank correlation) between species, eihght showed significant correlation (Table 4).
Effect of latitudinal gradient and shrublandcondition on the relative abundance (density/ activity) and taxonomic richness of the Formicidae assemblage

The preference for latitudinal section of matorral was different among species (Table 2). Across matorral-condition, three out of four species showed preference for the Acacia salignapatch; Linepithema humile, in turn, showed 
Table 2. Distribution of relative abundance of epigean ants inhabiting a latitudinal transect $\left(30^{\circ}-32^{\circ} \mathrm{S}\right)$ of coastal matorral of semiarid Chile.

\begin{tabular}{|c|c|c|c|c|c|c|c|c|}
\hline & $\mathrm{N}$ & & & & & & & \\
\hline \multirow[t]{2}{*}{ Ant species* } & \multicolumn{2}{|l|}{ MEC } & \multicolumn{2}{|l|}{ MEB } & \multirow{2}{*}{$\begin{array}{c}\text { MEA } \\
\mathrm{n}\end{array}$} & \multicolumn{3}{|c|}{ TOTAL } \\
\hline & $\mathrm{n}$ & $\%$ & $\mathrm{n}$ & $\%$ & & $\%$ & $\mathrm{n}$ & $\%$ \\
\hline $\mathrm{CM}$ & 74 & 0.17 & 3659 & 8.56 & 237 & 0.55 & 3970 & 9.28 \\
\hline LH & 2326 & 5.44 & 830 & 1.94 & 2669 & 6.24 & 5825 & 13.62 \\
\hline PB & 3554 & 8.31 & 666 & 1.56 & 3 & 0.01 & 4223 & 9.87 \\
\hline SG & 940 & 2.20 & 15169 & 35.47 & 1256 & 2.94 & 17365 & 40.61 \\
\hline TA & 4656 & 10.89 & 4831 & 11.30 & 1897 & 4.44 & 11384 & 26.62 \\
\hline Total & 11550 & 27.01 & 25155 & 58.82 & 6062 & 14.17 & 42767 & 100.00 \\
\hline
\end{tabular}

*Code for species: CM: Camponotus morosus; LH: Linephitema humile; PB: Pogonomyrmex spinosus; SG: Solenopsis gayi; TA: Tapinoma antarcticum. Code for PLV, MEC, MEB, MEA: see Figure 1.

Table 3. Distribution of relative abundance (density-activity) of epigean ants across condition of matorral in a latitudinal transect $\left(30^{\circ}-32^{\circ} \mathrm{S}\right)$ of semiarid of Chile.*

\begin{tabular}{|c|c|c|c|c|c|c|c|c|}
\hline \multicolumn{9}{|c|}{ Matorral condition } \\
\hline \multirow[t]{2}{*}{ Species } & \multirow{2}{*}{$\frac{\text { DES }}{\mathrm{n}}$} & \multicolumn{3}{|c|}{ ASA } & \multirow{2}{*}{$\frac{\text { VSN }}{n}$} & \multicolumn{3}{|c|}{ Total } \\
\hline & & $\%$ & $\mathrm{n}$ & $\%$ & & $\%$ & $\mathrm{n}$ & $\%$ \\
\hline $\mathrm{CM}$ & 552 & 1.29 & 2644 & 6.18 & 774 & 1.81 & 3970 & 9.28 \\
\hline LH & 2619 & 6.12 & 1350 & 3.16 & 1856 & 4.34 & 5825 & 13.62 \\
\hline PB & 826 & 1.93 & 779 & 1.82 & 2618 & 6.12 & 4223 & 9.87 \\
\hline SG & 5659 & 13.23 & 8862 & 20.72 & 2844 & 6.65 & 17365 & 40.60 \\
\hline TA & 1998 & 4.67 & 5536 & 12.94 & 3850 & 9.00 & 11384 & 26.62 \\
\hline Total & 11654 & 27.25 & 19171 & 44.83 & 11942 & 27.92 & 42767 & 100.00 \\
\hline
\end{tabular}

*Code for matorral condition: DES: degraded (desertified) patch; ASA: Acacia saligna-aforested patch; VSN: patch with semi-natural vegetation; code for ant species as in Table 2.

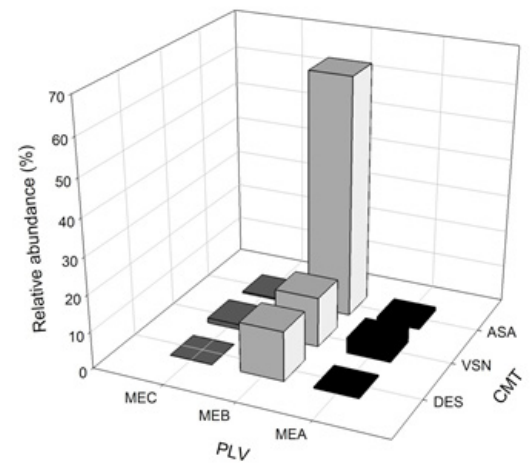

Figure 2. Distribution of relative abundance (density-activity) of Camponotus morosus across PLV and shrubland condition (CMAT). Code for PLV as in Figure 1. Code for CMT: DES: degraded (desertified) condition; VSN: semi-natural vegetation; ASA: Acacia saligna-aforested condition. Bars show percent of total captures. 


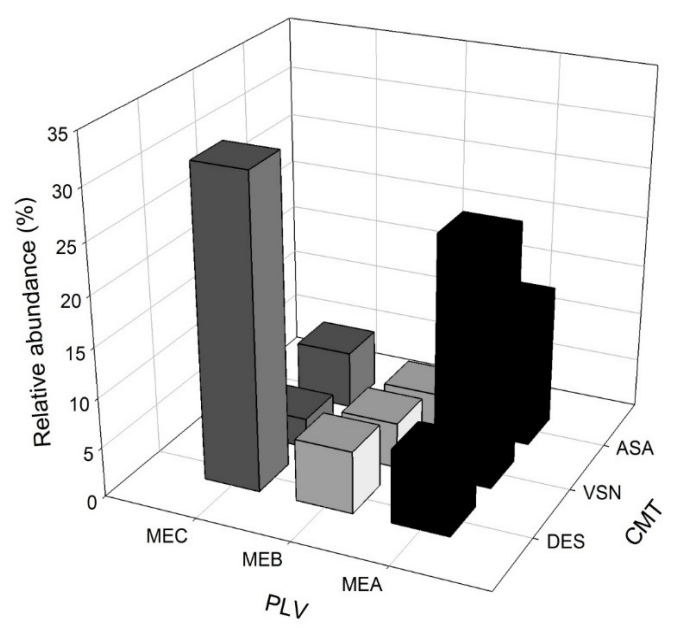

Figure 3. Distribution of relative abundance (density-activity) of Linepithema humile across PLV and CMAT. Codes for PLV and CMAT as Figures 1 and 2, respectively. Bars as in Figure 2.

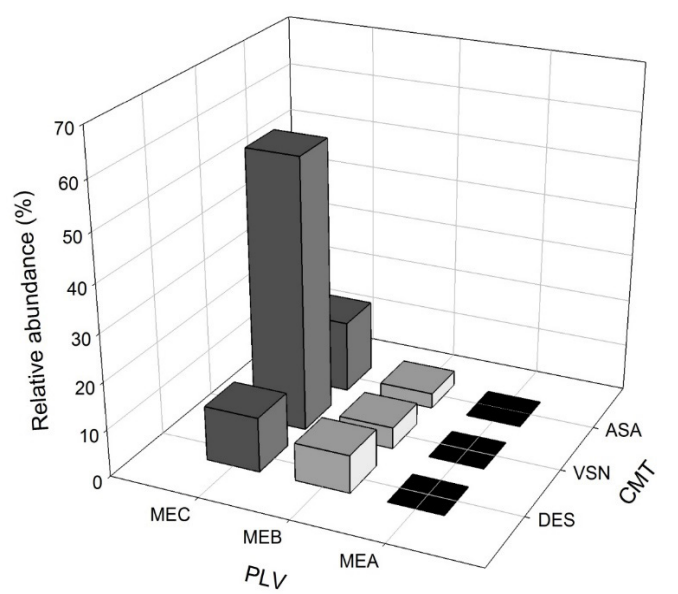

Figure 4. Distribution of relative abundance (density-activity) of Pogonomyrmex bispinosus across PLV and CMAT. Codes for PLV and CMAT as in Figures 1 and 2, respectively. Bars as in Figure 2.

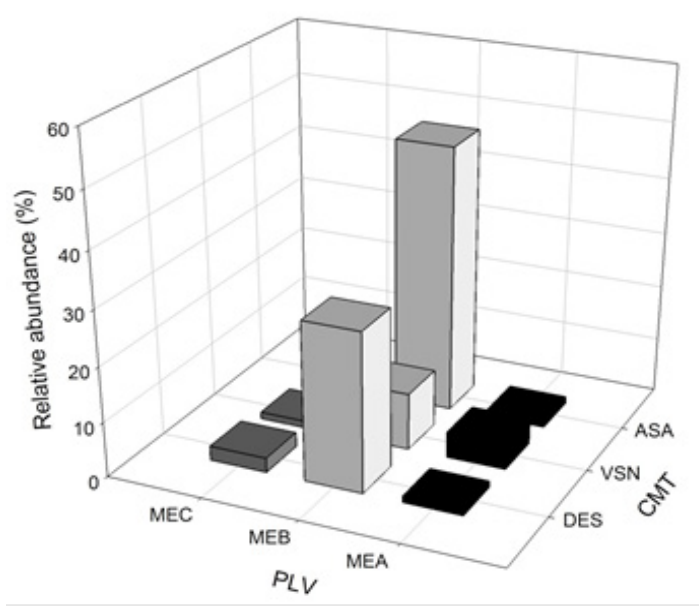

Figure 5. Distribution of relative abundance (density-activity) of Solenopsis gayi across PLV and CMAT. Codes for PLV and CMAT as in Figures 1 and 2, respectively. Bars as in Figure 2.

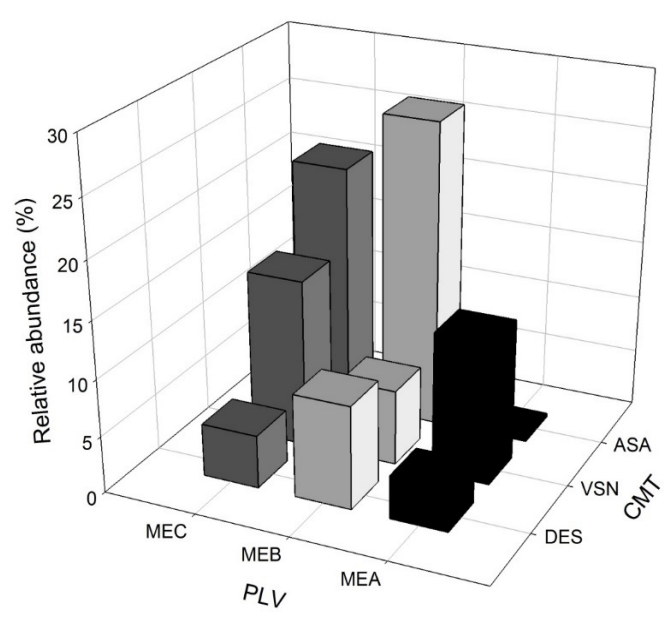

Figure 6. Distribution of relative abundance (density-activity) of Tapinoma antarcticum across PLV and CMAT. Codes for PLV and CMAT as in Figures 1 and 2, respectively. Bars as in Figure 2. 
Table 4. Coefficients of correlation (non-parametric Spearman's @) of relative abundance between pairs of ant-species inhabiting a coastal transect $\left(30^{\circ}-32^{\circ} \mathrm{S}\right)$ of semiarid Chile.

\begin{tabular}{lcc}
\hline Species * & $\varrho$ & Prob $<\mathrm{p}$ \\
\hline $\mathrm{SG} / \mathrm{TA}$ & 0.248 & $<0.01 * *$ \\
$\mathrm{~PB} / \mathrm{TA}$ & 0.432 & $<0.01 * *$ \\
$\mathrm{~PB} / \mathrm{SG}$ & 0.147 & 0.128 \\
$\mathrm{LH} / \mathrm{TA}$ & -0.222 & $0.021^{*}$ \\
$\mathrm{LH} / \mathrm{SG}$ & 0.309 & $<0.01 * *$ \\
$\mathrm{LH} / \mathrm{PB}$ & -0.287 & $<0.01 * *$ \\
$\mathrm{CM} / \mathrm{TA}$ & 0.283 & $<0.01 * *$ \\
$\mathrm{CM} / \mathrm{SG}$ & 0.727 & $<0.01 * *$ \\
$\mathrm{CM} / \mathrm{PB}$ & 0.091 & 0.331 \\
$\mathrm{CM} / \mathrm{LH}$ & 0.215 & $0.025^{*}$ \\
\hline
\end{tabular}

*Species code: as in Table 2.

preference for the degraded-patch (Table 3). The highest number of species was recorded in the three patch-types of matorral in the middlesection of transect (Table 5).

\section{Discussion}

\section{Taxonomic structure of the Formicidae assemblage}

For the study area, the endemic species recorded as well as the introduced one are in correspondence as previously documented
(Snelling \& Hunt, 1975). Biological and field ecology information about the recorded species are rather scanty in Chile (Torres-Contreras, 2001). Functionally, S. gayi and P. bispinosus are considered granivorous (Vásquez et al., 1995) and C. morosus has been reported to feed on dead insects, vertebrate faeces, and plant-detritus (Grez et al., 1986). Compared to the aforementioned species, T. antarcticum is much lesser known (Torres-Contreras, 2001). In southwestern North America, whereas Tapinoma species show opportunistic behavior, Linepithema humile behaves in an opportunistic way, dominating over native species (Andersen, 1997). Until now, in Chile, the economic importance, the invasive capacity and the aggressive behavior of this species, have attracted most of the interest of researchers (Torres-Contreras, 2001, Torres-Contreras et al., 2014). International literature holds that habitat fragmentation, exotic vegetation, urbanization, deforestation and high rainfall, specially if takes place during summer, facilitate penetration of L. humile; in turn, high temperatures and low humidity prevent ti. MacMahon et al. (2000) point out that $L$. humile displaces native species via competitive interference. We have no Chilean information exploring this topic. Out of the four paired correlations between relative abundances involving $L$. humile, two showed positive correlation (S. gayi and C. morosus) and two showed negative correlation (T. antarcticum and $P$. bispinosus). In this work, L. humile occupies

Table 5. Estimation of taxonomic richness of assemblage of epigean ants inhabiting a transect $\left(30^{\circ}-32^{\circ} \mathrm{S}\right)$ of coastal matorral of semiarid Chile.

\begin{tabular}{lccccccccc}
\cline { 2 - 9 } & \multicolumn{9}{c}{ Latitudinal section of matorral } \\
\cline { 2 - 9 } & \multicolumn{3}{c}{ MEC } & \multicolumn{3}{c}{ MEB } & \multicolumn{2}{c}{ MEA } \\
\cline { 2 - 9 } & SDE & VSrubland condition & \multicolumn{2}{c}{ shrubland condition } \\
\hline Estimator & 4 & 4 & 5 & 5 & 5 & 5 & 4 & 5 & 4 \\
\hline Chao \& Lee 1 (ACE) & 4.9 & & & & & & 5.9 & 5.8 \\
Jackknife 1st order* & $(0.9)$ & $4(0)$ & $5(0)$ & $5(0)$ & $5(0)$ & $5(0)$ & $4(0)$ & $(0.9)$ & $(1.8)$ \\
Pooled rarefaction** & $4(0.01)$ & $4(0)$ & $5(0)$ & $5(0)$ & $5(0)$ & $5(0)$ & $4(0)$ & $5(0)$ & $4(0)$ \\
$\mathrm{N}^{\circ}$ observed ant species & 4 & 4 & 5 & 5 & 5 & 5 & 4 & 5 & 4 \\
\hline
\end{tabular}

In parenthesis: * standard deviation; ** standard error; code for latitudinal section of matorral as in Figure 1; code for matorral condition as in Table 3. 
the third place in terms of numerical dominance, superseding the endemic species C. morosus and $P$. bispinosus. This fact may reflect the overall degradation condition of the studied transect and that invasion by L. humile is an active process in the area.

\section{Responses of species richness and relative abundance to latitudinal gradient}

Two Chilean myrmecofauna-hotspots have been recognized: the area extending from $30^{\circ}$ to $37^{\circ} \mathrm{S}$ (10 species) and the area extending from $37^{\circ}$ to $45 \mathrm{~S}$ (eight species) (Snelling \& Hunt, 1975). More recent work has increases richness for tract 30-37 S (Sáiz \& Carvajal, 1990; Solervicens et al., 1991; Solervicens \& Estrada, 2002). Since the segment covered by our study is an ecotonal band located between the Atacamenian zone (18-30 S), almost devoid of ant species, and central Chile $\left(30-37^{\circ} \mathrm{S}\right)$, the section so far richer, the decrease in species richness found in our study is an expected result. We observed a latitudinal effect on distribution of ant abundance. This effect was species-specific. This kind of response seems to be common within Formicidae (Sáiz \& Carvajal, 1990). We recognize three situations, two of them related to the endemic species and one related to the introduced one. The first case is $P$. bispinosus, whose relative abundance decreases in the southward direction. The second case involves C. morosus, S. gayi and T. antarcticum, which tend to prefer the middle segment of the studytransect. The third case involves $L$. humile, which showed no preference whatsoever, as expected for an invasive species. We have no a clear answer for the observed latitudinal effect. The list of possible determining factors is extensive in published literature. Among the principal ones are those related to altitude and aridity gradients, soil type heterogeneity, landscape characteristics, and seasonal variation in rainfall and temperature (MacMahon et al., 2000; Dunn et al., 2007; Crist, 2009). Our study-transect did not show major differences in physiographic features, soil characteristics, and annual air temperatures; however, it shows a historical rainfall gradient that is reflected from north to south in the main characteristics of seminatural matorral (open low matorral to sclerophyllous matorral) (Luebert \& Pliscoff, 2006). Nevertheless, as a result of intense agropastoral activities practiced in the area since early post-colonial time, this matorral is altered in different degrees of intensity (Rolando, 2003). Given that human pressure has not been the same across the study-transect, we advance the idea that these human induced conditions are one of the main responsible for the observed effect of latitude, reinforcing a site effect over a gradient effect.

\section{Formicidae responses to shrubland alteration}

Most research examining the effects of disturbances on the epigean fauna is based on pseudo-experimental designs. We followed this approach and are well aware of its limitations. In fact, these designs use as treatment variables the field's prevailing conditions, usually a result of landscape management. The data obtained from these studies in many cases contains a large amount of "noise". This noise is the result not only of lack of control the researcher has over treatment variables, but also it is due to the natural variability of these systems, especially in studies covering wide areas. Probably, this noise is one of the reasons of the inconsistent results obtained in studies about the responses of ants to habitat alterations conducted in desert sites (Whitford et al., 1999; Nash et al., 2000, 2004; Bestelmeyer, 2005; Hoffmann, 2010). We are well aware we were exposed to this kind of noise. When designing the work, we hypothesized that the seminatural patches would show higher relative abundance and richness, following the rainfall gradient and/or matorral semipristinity. Our study did not provided fully evidence in this direction, but agrees well with the site effect hypothesis. Given that the knowledge on the biology of Chilean ants species is quite poor (Torres-Contreras, 2001), a deeper interpretation of our results was not feasible, evidencing the need to improve the knowledge of the natural history of the mirmecofauna, common elements in many arid regions, among them northern Chile.

\section{Conclusions}

We recorded the presence of five, possibly six, ant species. This richness is lower than that reported from central Chile and other arid regions. Four recorded species were native. There was no evidence on the effect of latitudinal gradient 
or matorral condition. Ants' responses were found to be site and species-specific. We interpret these results as the combined effects of local natural features (e.g., climate pattern, landscape physiography, vegetation, and soil), interplaying with derived from human actions.

\section{Acknowledgments}

We are grateful to J. Ipinza-Regla for taxonomical confirmation of ant-species. Extend our thanks to Eduardo Collantes, owner of the Caracas Farm, and managers of farms Sociedad Agrícola Lagunillas S.A. and Comunidad Agrícola Alcones Altos for allowing us to deploy our study sites. The captured material was taxonomically processed by H. Vásquez. The following F. Alfaro, M. Cortés, P. Agusto, and J. P. Castillo assisted in field and lab work. Funding for this research was provided by the Research Office of the University of La Serena under the PR14121 Project (J. CepedaPizarro).

\section{Literature Cited}

Alfaro, C. W.

2006. Implementación en Chile de la Convención de Naciones Unidas contra la Desertificación de los países afectados por sequía grave o desertificación, en particular África, Tercer Informe Nacional, Santiago, Chile. 36 p.

Andersen, A. M.

1997. Functional groups and patterns of organization in North American ant communities: a comparison with Australia. Journal of Biogeography, 24: 433-460.

Bestelmeyer, B. T.

2005. Does desertification diminish biodiversity? Enhancement of ant diversity by shrub invasion in southwestern USA. Diversity and Distributions, 11: 45-55. CONAMA.

2006. Estudio de la variabilidad climática en Chile para el siglo XXI. Informe final, Santiago, Chile. 63 p.

Bars, G.

2002. Estrategia de la Corporación Forestal en el combate a la desertificación en la Región de Coquimbo. In Universidad de Chile, (ed.) Avances en restauración ambiental con énfasis en recuperación ecológica. Publicaciones Misceláneas Forestales, Santiago,Chile. pp. 41-46.

Crist, T.

2009. Biodiversity, species interactions, and functional roles of ants (Hymenoptera: Formicidae) in fragmented landscapes: a review. Myrmecological News, 12: 3-13.

Dunn, R. R.; Parker, C. R.; Sanders, N. J.

2007. Temporal patterns of diversity: Assessing the biotic and abiotic controls on ant assemblages. Biological Journal of the Linnean Society, 91: 191-201.

Grez, A. A.; Simonetti, J. A.; Ipinza, J. H.

1986. Hábitos alimenticios de Camponotus morosus (Smith, 1858) (Hymenoptera: Formicidae) en Chile Central. Revista Chilena de Entomología, 13: 51-54.

Hoffmann, B. D.

2010. Using ants for rangeland monitoring: Global patterns in the responses of ant communities to grazing. Ecological Indicators, 10: 105-111.

Luebert, F.; Pliscoff, P.

2006. Sinopsis bioclimática y vegetacional de Chile. Editorial Universitaria, Santiago. 316 p.
MacMahon, J. A.; Mull, J. F. and Crist, T.O.

2000. Harvester ants (Pogonomirmex spp.): Their community and ecosystem influences. Annual Review of Ecology and Systematics, 31: 265-291.

Nash, M. S.; Bradford, D. F.; Franson, S. E.; Neale, A. C.;

Whitford, W. G.; Heggem, D. T.

2004. Livestock grazing effects on ant communities in the eastern Mojave Desert, USA. Ecological Indicators 4: 199-213.

Nash, M. S.; Whitford, W. G.; Van Zee, J.; Havstad, K. M. 2000. Ant (Hymenoptera: Formicidae) responses to environmental stressors in the Northern Chihuahuan Desert. Environmental Entomology, 29: 200-206.

Pérez, C.; González, J.

2001. Diagnóstico sobre el estado de la degradación del recurso suelo en el país. Instituto de Investigaciones Agropecuarias (INIA), Chillán, Chile. 196 p.

Rolando, N.

2003. Diagnóstico y perspectivas de la situación agropecuaria de la Región de Coquimbo. In Livenais, P., Aranda, X. (eds.) Dinámicas de los sistemas agrarios en Chile árido: La región de Coquimbo. LOM ediciones, Santiago, Chile. pp. 219-239.

Sáiz, F.; Carvajal, C.

1990. Incendios forestales en el Parque Nacional La Campana, sector Ocoa, V Región, Chile. Blattodea, Formicidae y Mutilidae. Impacto y recuperación. Anales del Museo de Historia Natural de Valparaíso, Chile, 21: 51-61.

Seaby, R. M. H.; Henderson, P. A.

2007. Diversity \& Richness IV- Instruction Manual. Pisces Conservation Ltd, Lymington, Hampshire. 123 p.

Snelling, R. R.; Hunt, J. H.

1975. Ants of Chile (Hymenoptera: Formicidae). Revista Chilena de Entomología, 9: 63-129.

Solervicens, J.; Estrada, P.

2002. Insectos epígeos de asociaciones vegetacionales esclerófilas de la Reserva Nacional de Río Clarillo (Región Metropolitana, Chile). Acta Entomológica Chilena, 26: 27-44.

Solervicens, J.; Estrada, P.; Márquez, M.

1991. Observaciones sobre entomofauna de suelo y follaje en la Reserva Nacional Río Clarillo Región Metropolitana, Chile. Acta Entomológica Chilena, 16: 161-182. 
Torres-Contreras, $\mathrm{H}$.

2001. Antecedentes biológicos de hormigas presentes en Chile publicados en revistas científicas nacionales y extranjeras durante el siglo XX. Revista Chilena de Historia Natural, 74: 653-668.

Torres-Contreras, H.; Canals, M.; Castro, S. A.; Jaksic, F. M. 2014. Invasión de la hormiga argentina (Linepithema humile) a escala biogeográfica. In Jacksic, F. M., Castro, S. A. (eds.) Invasiones biológicas en Chile: Causas globales e impactos locales. Ediciones UC, Santiago, Chile, pp. 309-340.
Vásquez, R. A.; Bustamante, R. O.; Simonetti, J. A.

1995. Granivory in the Chilean matorral: extending the information on arid zones of South America. Ecography, 18: 403-409.

Whitford, W. G.

2001. Invertebrates: their effects on the properties and processes of desert ecosystems. In Prakash, I. (ed.) Ecology of Desert Environments. Scientific Publishers, Jodhpur. pp. 333-356.

Whitford, W. G.; Van Zee, J.; Nash, M.

1999. Ants as indicators of exposure to environmental stressors in North American desert grasslands. Environmental Monitoring and Assessment, 54: 143-171. 